\title{
Nanotechnology, a revolutionary technique in the food industry: systematic review
}

\section{Nanotecnología, una técnica revolucionaria en la industria alimenticia: una revisión sistemática}

\author{
Tejas R Suthar, Abhishek B Gavane, Akshay Y Shah, Anupama N Devkatte \\ MIT College of Food Technology, MIT ADT University, Pune, India. \\ Author for correspondence: suthartejas2525@gmail.com
}

\begin{abstract}
Nanotechnology has a great role in food industry in terms of processing, packaging, preservation and storage. It provides a wide variety of possibilities in food industry applications. This technology is now leading in the main field of food industry with the development of other technologies as well. Nanoencapsulation technique is widely know for successful delivery of nutrients in body with application of bioactive compound. In addition, nanoencapsulation enables the control of flavour release during processing and storage at the desired time and the prevention of flavour degradation. The use of nano biosensors in packaging technique that definitely detects harmful components in food, pathogen identification, changes in food characteristics and food quality. Nonetheless, there is no question that nanotechnology is making a significant contribution to the newly developed advanced technique but safety is also a major concern, when it comes to the use of this technique in food industry, growth and protection should be pushed in parallel to the overall progress of the food industry and consumers.
\end{abstract}

Keywords: Nanotechnology, Applications, History, Nanoencapsulation

\section{RESUMEN}

La nanotecnología tiene un gran papel en la industria alimentaria en términos de procesamiento, envasado, conservación y almacenamiento. Proporciona una amplia variedad de posibilidades en aplicaciones de la industria alimentaria. Esta tecnología es ahora líder en el campo principal de la industria alimentaria con el desarrollo de otras tecnologías también. La técnica de nanoencapsulación es ampliamente conocida por la entrega exitosa de nutrientes en el cuerpo con la aplicación de compuestos bioactivos. Además, la nanoencapsulación permite el control de la liberación de sabor durante el procesamiento y almacenamiento en el momento deseado y la prevención de la degradación del sabor. El uso de nano biosensores en la técnica de envasado que detecta definitivamente componentes dañinos en los alimentos, identificación de patógenos, cambios en las características de los alimentos y la calidad de los alimentos. No 
obstante, no hay duda de que la nanotecnología está haciendo una contribución significativa a la técnica avanzada recientemente desarrollada, pero la seguridad también es una preocupación importante, cuando se trata del uso de esta técnica en la industria alimentaria, el crecimiento y la protección deben impulsarse en paralelo a la progreso general de la industria alimentaria y los consumidores.

Palabras clave: Nanotecnología, historia, Nanoencapsulación

\section{INTRODUCTION}

The present world population stands at 7.8 billion people, and by 2037 is expected to reach 9 billion. A significant proportion of those living in developing countries are facing daily food shortages as a result of environmental changes or political turmoil, while there is a food surplus in the advanced world. Scientists have been researching and working with nanoparticles for hundreds of years but their inability to view the nanoparticles construction has impeded their performance. In recent decades, the invention of microscopes able to view objects as small as atoms has allowed scientists to see beyond what they are dealing with.

Nanotechnology's potential has been well-publicized in a variety of sectors such as drug delivery, fabrics, metal reactivity, material strength, nanoelectromechanical device, molecular processing, fuel cells, solar cells, chemical sensors, space etc. Several nanotechnology merchandises are already inside the market, which include anti-bacterial dressings, transparent sun screen creams, stain-free fabrics, non-scratch paints, and self-cleansing windows. According to National Nanotechnology Initiative (NNI) it has been stated that nano technique is moving way beyond our imagination. Nanotechnology is implicating its benefits in everyday material handling, processes, electronics, IT applications, medical, healthcare applications, energy applications and environment remediation. Nanotechnology uses nanomaterials to construct fast performance computers. Nano technique is used to create quantum dots that can go into the body of the human to identify and fight diseases. Chemistry is the missing tool for moving nanotechnology to the next generation. The chemistry needs to be there which can help in arranging billion of nano particles (NNI, 2020). In addition to this, the application of nanotechnology is also growing day by day in the food sector. A study released by the US Department of Agriculture in September 2003 addressed the application of nanotechnology to the agricultural and food industries (Krishnakumar T. 2019). Nanotechnology is expected to change the entire food industry through the transformation of food processing, production, packaging, transportation and consumption. The analysis focuses primarily on food nanotechnology applications and includes numerous applications related to food processing, food storage, food preservation and food safety. The purpose of this review is to identify the nanotechnology circumstances used in the field of food sector, and to give nanotechnology researchers a detailed perspective.

\section{NANOTECHNOLOGY}

Nanotechnology is described as the manufacture, use and handling of nanometer-sized materials, instruments or systems. The term nano comes from the Greek terms, for a small number. A nanometer is 1000th of 1000th of 1000th of a meter $\left(10^{-9}\right.$ meters). For example, one nanometer is around 60,000 times smaller than a human hair in diameter or the similar scale to the virus (Arafat et al., 2019). Usually Nanomaterials are defined as materials of 
between $1 \mathrm{~nm}$ to $100 \mathrm{~nm}$ size (Hyunjong et al., 2018). Nanotechnology is the experimental technique that addresses small particles and has a significant effect on food production, processing, preservation and packaging (Anu et al., 2015). Due to the nature of nanoparticles which contribute to a wide range of different applications, their physio-chemical characteristics dramatically alter. Despite the reality that the idea of nanotechnology remains new, but its implementations has been utilized technologically for several years, and was part of the secret information that came back a few years ago. Since life came into being, nanotechnology has observed and came into attraction as it can be clearly seen in the development of DNA into nano-sized proteins and performing functions on a much smaller scale while having a huge effect on the whole structure of organism and its function can be clearly seen in the uniqueness of nanotechnology (Khan et al., 2015). Research on this topic has increased in the last decade. It includes nearly every part of the food and agricultural industry including livestock, water management for irrigation /waste water, food production and storage, packaging, animal feed, and aquaculture (Xiaojia et al., 2018). In recent years, considerable advances in nanotechnology have opened up a new era in industrial technology. The technology brings its advantages to the marketing of novel nanomaterial-based articles in almost all food sectors in manufacturing and enhances the quality of processing, food characteristics, taste and safety (Xiaojia et al., 2018). This nanotechnology often applies to the technique of tissue engineering that can be used in the processing of cultured meat where the scale of myotube cells is small and also allows the composition of cultured/lab grown meat to be reconstituted (Suthar et al., 2019). And this technique also leads and produces food of higher quality and greater nutritional value by applying knowledge in nanotechnology and its use in the food sciences (Khan et al., 2015).

At this juncture, nanotechnology conjointly depicting wide range of applications in the food industry, such as the manufacture of processed nanostructured foods e.g. mayonnaise, the use of nanocarrier as an efficient supply of nutrients and supplements e.g. nanosize powders for improved nutrient absorption, nanocapsules infused with plant-based steriods to substitute meat cholesterol, nanosensors are used in agriculture to obtain highly valuable data like soil, moisture, $\mathrm{pH}$. Various types of nanomaterials (silver, magnesium, zinc) are used to make the antimicrobial, antifungal and stronger packaging material (Nanotechnology in Food, 2020).

\section{HISTORICAL BACKGROUND}

American physicist Richard Feynman presented the idea of nanotechnology in 1959. Feynman defined a method for manipulating individual atoms and molecules, using a collection of specific tools to build and operate another collection which is comparatively smaller at the appropriate level.

This groundbreaking method has shown that Feynman's predictions have been shown to be right, and he is considered the father of modern nanotechnology for that. The first MOSFET (metal-oxide semiconductor field-effect transistor) of $100 \mathrm{~nm}$ gate Oxide thickness and a gate length of $20 \mu \mathrm{m}$ was produced in 1960 by Egyptian engineer Mohamed Atalla and Korean engineer Dawon Kahng in Bell Labs (Sze et al., 2002). In 1962, Atalla and Kahng developed a nanolayer-based metal - semiconductor junction ( $\mathrm{M}$ - $\mathrm{S}$ junction) transistor, using $10 \mathrm{~nm}$ thin gold (Au) films (Pasa, 2010). In 1986, K. Eric Drexler " in his book Engines of Creation: The Coming Era of Nanotechnology, said the word "nanotechnology indicating the 
idea of a nanoscale "assembler" capable of making a copy of itself and other arbitrary objects with atomic control (Drexler, 1986).

In 1991, Iijima et al. experiential found the hollow graphitic tubes or carbon nanotubes by Transmission Electron Microscopy (TEM) which identified similar member as the fullerene family. The flexibility and strength of carbon nanotubes in many nanotechnological applications make them potentially useful (Iijima et al., 1991).

In 2004, during the purification of single-carbon nanotubes $\mathrm{Xu}$ et al. inadvertently discovered a new class of carbon nanomaterials called carbon dots ( $C$-dots) with sizes below $10 \mathrm{~nm}$ ( $\mathrm{Xu}$ et al., 2004). Due of its safe, abundant and inexpensive existence, C-dots with interesting properties have slowly become an essential part of nanocarbon and these C-dots are attractive materials used in bio-imaging, bio-sensor and drug delivery applications (Baker et al., 2010).

Nucleic acid is one of the most important contribution to molecular biology. In 2006, by improving the complexity and size of self-assembled DNA nanostructures in a "one-pot" reaction, Paul Rothemund made the experiment and developed the "scaffolded DNA origami" (Rothemund, 2006).

NNI (National Initiative for Nanotechnology) is a U.S. Government research and development (R\&D) program involving 20 departments and government agencies in the activities related to nanotechnology. NNI's budget for financing nanoscience, engineering and development was $\$ 1.2$ billion in 2018 . Today researchers are aiming to make life for humans safer and more comfortable through recent development in nanoscience and nanotechnology.

The advancement of nanotechnology in the fields of science, has expanded in various fields to investigate objects from micro to nano, to very minor scale. Nanotechnology and nanoscience have become increasingly relevant for industrial applications and medical devices in just a few years. Nanotechnology has covered many industries including engineering, chemical technology, instruments manufacturing, petrochemical engineering and many more. In Food sector also nanotechnology is paying a key role in advancement of technologies related to food processing, food preservation, food packaging and food safety. Different type of nanomaterials is used in the manufacture of biosensors/nanobiosensors that can detect the almost all the physical, chemical and biological properties of food within its packaging.

\section{APPLICATION OF NANOTECHNOLOGY IN FOOD INDUSTRY}

Nanotechnology has been slowly seen over the last few decades as promising technology that has revolutionized the food industry. This technology deals with nanometer sized particles such as atoms, macromolecules nearly size of 1-100 nm to develop materials with innovative properties. Currently, consumers seem to be more concerned about safety and seeking health benefits from a particular food article and to overcome this issue, leading researchers are finding ways to improve food quality while at the very least reducing the nutritional value of the product. The demand for materials based on nanoparticles has increased in the food industry because many of them hold important elements and are considered to be non-toxic (Roselli et al., 2003).

Application of nanotechnology in the food sector can be abridged in two major categories which are nanostructured food ingredients and food nanosensing. Nanostructured food 
ingredients cover a wide range of sectors from food production to food packaging. Such nanostructures can be used as food additives in food processing, carriers for smart nutrient delivery, anti-oxidative agents, anti-caking agents, antimicrobial agents, fillers to improve the mechanical strength and durability of the packaging material, etc., though nanosensing of foods can be used to achieve improved food quality and health assessment (Ezhilarasi et al., 2013). Nanotechnology can be used in many applications within food industry. The application of nanotechnology in this study covers primarily food Processing, food security or preservation, food Packaging and food safety or health (Fig.1)

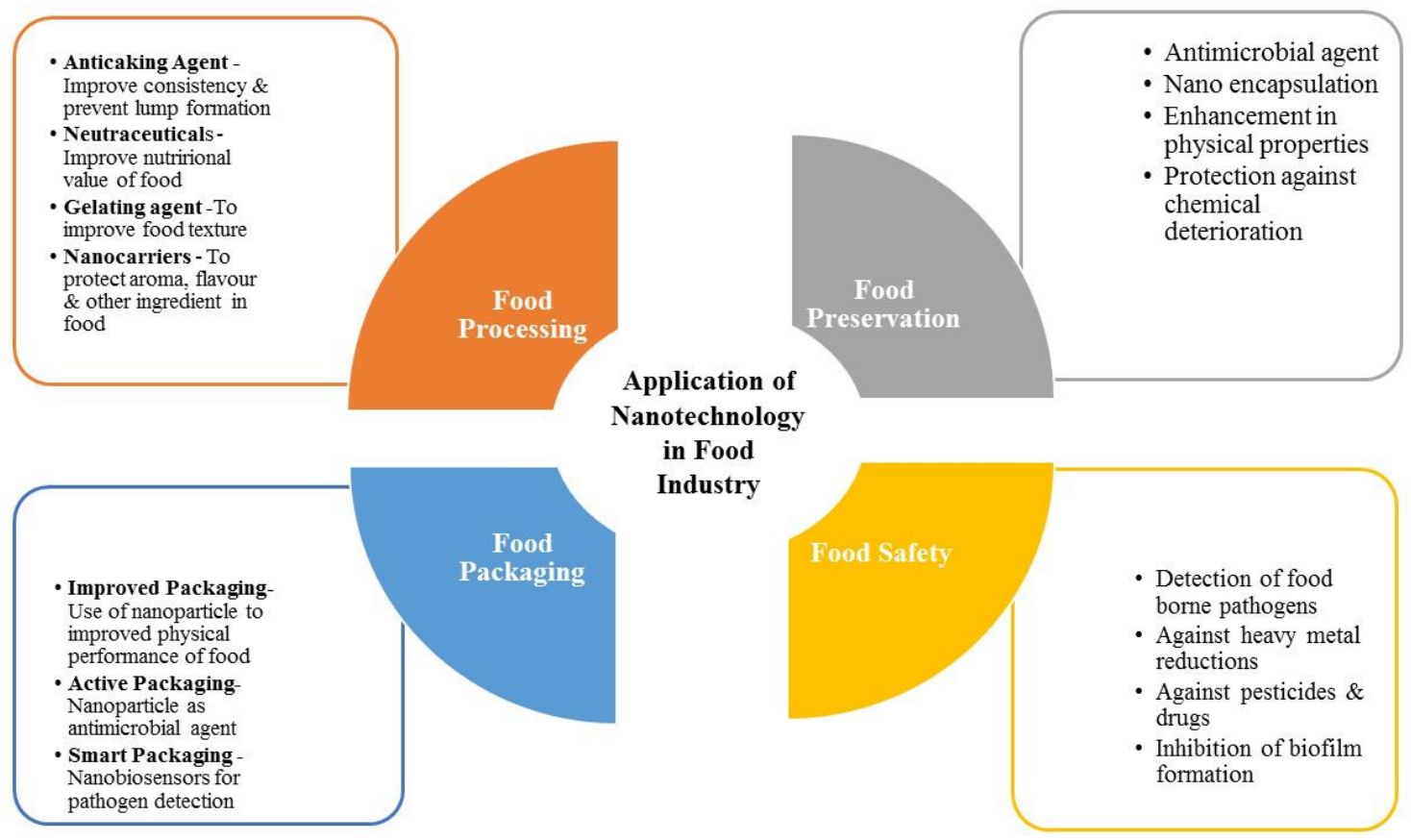

Fig.1: Nanotechnology Application in Food Industry

\section{FOOD PROCESSING}

Through nanotechnology novel food processing techniques were applied to determine the sensory and technological properties of foods. Organic components such as proteins, lipids and carbohydrates of different types are naturally found in foodstuffs and have used various functions in food processing (He and Hwang 2016; Ravichandran 2010). Nanocapsules were used as nano-sized ingredients, additives, dietary supplements and in functional foods in food processing (Momin et al., 2013). Cushen et al., (2012) recorded that nanoencapsulation of food ingredients and additives was performed to improve protective barriers property, flavors and taste enhancement, controlled release, and enhanced less water-soluble food ingredients and additives dispensability.

Nanoparticles were added during food processing to incorporate high nutritional content, flow properties, taste, color and stability or to increase the shelf life. Today Nanocarriers are used as delivery systems to hold food additives in food products that do not affect their basic morphology. The particle size may have a direct effect on the effectiveness of any bioactive compound to various sites within the body, as many research studies have found or reported that only submicron nanoparticles can be engrossed efficiently in certain cell lines but not the macroparticles (Ezhilarasi et al., 2013). 
Nanotechnology is used in food processing for:

- Alteration of macroscales character e.g. texture, sensory quality, processability and shelf life.

- Understanding the role of food components and its interaction.

- Develop healthier, tastier and safer food.

- Manufacturing of lighter and more accurate food equipment.

- Development of 'smart' packaging materials.

- Development of novel delivery methods.

- Manufacture of sensors for detection of food pathogens.

Public concern about the toxicity and contrary impact of nanoparticles on human health and environment is growing. Therefore, it is recommended to develop are regulatory framework that will analyze the satisfactory limits on the use of nanomaterials in different food processing activities.

\section{FOOD PRESERVATION}

Food preservation has been described as "the science dealing with the process of preventing food degradation or spoilage so that it can be stored in a fit condition for future use." And the successful preservation of food can be clearly seen when there is no contamination by pathogenic organisms or chemical and there is no any nutrient loss identified. Different types of bioactive compounds are in functional food and are responsible for specific types of particular functions. This bioactive component is often weakened at times, and ultimately led to inactivation due to the hostile environment. Nanoencapsulation of the bioactive components led to increases the shelf-life of food articles by slowing down the certain processes such as degradation or it prevents degradation before delivery of the product at the target location (Singh et al., 2017). Nanoencapsulation is performed using nanocapsules. The design of nanocapsules depicts the outer core-shell structure in which particular drug is constrained within the cavity which is made of either polymer membrane or some coating. The cavity may contain active ingredients in different forms like solid or liquid or as dispersion of molecules. Nanocapsules bring the food supplement across the gastrointestinal tract of the biological system and this leads to an improved bioavailability of the product (Neha et al., 2015). Furthermore, edible nano-coatings on various food articles may create a barrier to the exchange of moisture and gas and include colours, aromas, antioxidants, enzymes and antibrowning agents, which may also improve the shelf-life of processed foods even after the packaging has been opened (Renton, 2006; Weiss et al., 2006). Table 1 illustrate the general uses of nanotechnology in food preservation.

\section{NANOENCAPSULATION}

Nanoencapsulation is characterized as the technology of packaging solid, liquid, or gas, nanoparticles also known as the core or active in forming nano capsules within a secondary material, called the matrix or shell (Augustin et al., 2009). Nanoencapsulation is the most noteworthy technology in food science and technology, particularly for bioactive compounds and flavors.

Targeted delivery systems built with nanoencapsulation can increase bioavailability after oral administration of bioactive compounds. In addition, nanoencapsulation enables the control 
of flavor release during processing and storage at the desired time and the prevention of flavor degradation. Nanocarrier encapsulation helps to continually release the flavor compounds and to retain the flavor content during the product's shelf-life. Sustained release can be carried out by encapsulating a compound in appropriate nanocarriers which preserves physical stability below the expected operating situations and durations (Hyunjong et al., 2018). Besides this, several researchers have focused on the nanoencapsulation techniques as shown in Table 2.

Table 1: Use of nanotechnology in food preservation

Sr.No. Uses/Concept References

1. Incorporating nanotech-based formulation may reduce dependency on other chemicals and it can help in the production of a wide range of agriproducts.

2. Top-down approach concept help in the preservation of food by breaking down bulk materials in nanoscale particle with the addition of colloidal protecting agent.

3. Nanobioluminescence Detection Spray can detect contaminated food by emitting glow while binding with microbes such as Salmonella and E. Coli.

4. Dispersion of carotenoid nanoparticle in water could be possible which will improve the bioavailability of fruit drink.

5. Nanotechnology can be used in the dairy industry for the effective delivery of bioactive compounds and preservation of product quality.

Pakeeza et al., 2019

Kavitha et al., 2017

Moustafa M, 2016

Seval K, 2015

Radha et al., 2014

6. Nanotechnology applications can reconstruct the food characteristics such as texture, color, strength, stability which will help in preserving the food.

7. In the future, the nanocapsule can replace the conventional system of transferring genetic material.

Shivendu et al., 2014

Agrawal S. and Rathore P, 2014

8. Nanofiltration technique is used for concentrating rosemary extract which acts as a preservative and functional ingredient in a different type of food.

9. Nanoliposomes and nanocochleates are used as a carrier for lipidbased antioxidants. It helps in stabilizing micronutrients by enhancing the nutritional quality and preserving the food articles.

10. Chinese industry is producing tea which nano-selenium enriched tea, which improves selenium uptake and bioavailability.

11. Some of the nanocarriers contain lycopene and beta-carotene that can evade cholesterol accumulation in the body.

12. Nanoparticle such as silver is being used in advanced packaging materials to improve the shelf life of food by killing microbes within 6 minutes.

13. Micofluidization is the technique used for size reduction and emulsion formation which enhances the texture of food and helps in increasing the shelf life of food.

Mazzocchi S, 2011

Chaudhry et al., 2008

Mozafari et al., 2006

Sherman M, 2005

Degant $O$ and Schwechten D, 2002 
Sustainability, Agri, Food and Environmental Research, (ISSN: 0719-3726), 9(1), 2021: 127-141 http://dx.doi.org/10.7770/safer-VONO-art2256

Table 2: Research work performed on technique of nanoencapsulation

\begin{tabular}{|c|c|c|}
\hline References & Title of article & Research content and Conclusion \\
\hline Yu et al., 2009 & $\begin{array}{l}\text { Synthesis and characterization } \\
\text { of novel antimicrobial } \\
\text { emulsifiers from -polylysine }\end{array}$ & $\begin{array}{l}\text { During nanoencapsulation e.g. the } \\
\text { food additives are surrounded in } \\
\text { nanocomposite polymer succinic- }\end{array}$ \\
\hline Sekhon, 2010 & $\begin{array}{l}\text { Food nanotechnology an } \\
\text { overview }\end{array}$ & $\begin{array}{l}\text { polylysıne Octenyl } \\
\text { controlled release }\end{array}$ \\
\hline Yu and Huang, 2010 & $\begin{array}{l}\text { Enhanced in vitro anti-cancer } \\
\text { activity of curcumin } \\
\text { encapsulated in hydrophobically } \\
\text { modified starch }\end{array}$ & $\begin{array}{l}\text { The efficacy of Curcumin against } \\
\text { cancer was strengthened by } \\
\text { encapsulation in hydrophobically } \\
\text { controlled starch }\end{array}$ \\
\hline Mozafari et al., 2006 & $\begin{array}{l}\text { Recent trends in the lipidbased } \\
\text { nanoencapsulation of } \\
\text { antioxidants and their role in } \\
\text { foods }\end{array}$ & $\begin{array}{l}\text { Usage of lipid-based totally } \\
\text { nanoencapsulation along with } \\
\text { nanoliposomes, nanocochleates, } \\
\text { and archaeosomes as a means of }\end{array}$ \\
\hline Mozafari et al., 2008 & $\begin{array}{lll}\text { Nanoliposomes } & \text { and } & \text { their } \\
\text { applications } & \text { in } & \text { food } \\
\text { nanotechnology } & & \end{array}$ & $\begin{array}{l}\text { enzymes, food preservatives and } \\
\text { antimicrobials }\end{array}$ \\
\hline $\begin{array}{l}\text { Vidhyalakshmi et al., } \\
2009\end{array}$ & $\begin{array}{l}\text { Encapsulation The future of } \\
\text { probiotics }\end{array}$ & $\begin{array}{l}\text { Probiotic nanoencapsulation was } \\
\text { achieved to target different regions } \\
\text { of the GI tract }\end{array}$ \\
\hline Gupta and Silver, 1998 & $\begin{array}{l}\text { Molecular Genetics: Silver as a } \\
\text { biocide: Will resistance become } \\
\text { a problem? }\end{array}$ & $\begin{array}{l}\text { The silica gel microsphere combined } \\
\text { with thiosulfate is used for long- } \\
\text { lasting antibacterial action }\end{array}$ \\
\hline Vargas et al. 2008 & $\begin{array}{l}\text { Recent advances in edible } \\
\text { coatings for fresh and minimally } \\
\text { processed fruits }\end{array}$ & $\begin{array}{l}\text { Nanocoating concept to be used as } \\
\text { a carrier of essential ingredients } \\
\text { during nanoencapsulation process. }\end{array}$ \\
\hline Rhim et al., 2006 & $\begin{array}{l}\text { Preparation } \\
\text { characterization of chitosan- } \\
\text { based nanocomposite films with } \\
\text { antimicrobial activity }\end{array}$ & $\begin{array}{l}\text { Edible chitosan related nanoparticle } \\
\text { films obtained by combining } \\
\text { nanoparticles made from } \\
\text { montmorillonites and nanosilver }\end{array}$ \\
\hline Kahand Hofman, 2014 & $\begin{array}{l}\text { Nanopesticide research: current } \\
\text { trends and future priorities }\end{array}$ & $\begin{array}{l}\text { In the process of nanopesticides } \\
\text { nanocapsules and nanoemulsions }\end{array}$ \\
\hline Kookana et al., 2014 & $\begin{array}{l}\text { Nanopesticides: guiding } \\
\text { principles for regulatory } \\
\text { evaluation of environmental } \\
\text { risks }\end{array}$ & $\begin{array}{l}\text { containing pure nanoparticles such } \\
\text { as metals, metal oxides and } \\
\text { nanoclays }\end{array}$ \\
\hline
\end{tabular}

\section{FOOD PACKAGING}

Food packaging and safety are key nanotech research and development priorities today. Food companies are working on packaging that incorporating lightweight and safer products with built-in sensors that can alert a client to contamination or the presence of pathogen. New advancement in Nano-based 'active' food packaging system provides many advantages over normal packaging such as improved mechanical strength, blocking properties, incorporated 
nano sensors (to detect pathogens) and deals with food safety concerns (Mihindukulasuriya and $\operatorname{Lim} 2014$ ).

Nanotechnology in food packaging involves the different materials and devices to be used such as nanoplastic packaging, nanocomposite, enhanced packaging, active packaging, intelligent packaging, electrical language processing, nanobiosensors use etc. Food Packages of food can be made lighter by adding other nanoparticles in packaging materials and bottles, with improved mechanical and thermal properties and resistant to burn. Application of nanocomposites as active material for packaging and surface coating can be used to enhance the consistency of food packaging (Pinto et al., 2013). By using the inorganic nanoparticles in less concentration and more stability, it will help in achieving strong antibacterial properties. Thus, nanoparticles have been used for antimicrobial packaging in recent years. Silver, chitosan, copper, titanium oxide or zinc oxide are the certain nanoparticles which have been reported for imparting antibacterial properties (Bradley et al., 2011; Tanet al., 2013)

Polymer Nanomaterial for Food Packaging (PNFP) is categorized according to its properties into three disciplines known as "Improved PNFP," "Active PNFP," and "Intelligent PNFP". Depending on their use they may be used as independent or collective. The Improved PNFP defines polymer strength, gas barrier properties, temperature stability and humidity while the two others deal with antimicrobial properties and sensitivity (Clara et al., 2011). Active PNFP food packaging is made to preserve the internal state of the food on a regular basis by preventing absorption and removal to the inside and out of the coating surface (Arora et al., 2005). Such polymer types are designed to detect microbial activity, UV and absorption resistance etc. The Smart or Intelligent PNFP which determines the temperature, humidity, oxygen level and microbial value of the packaged food. The nanobiosensors of the nanopolymer devices are used to detect the internal packaging conditions (Bhattachary et al., 2007).

In nanoscience, nanosensors are used as an immersion technique consisting of a series of specific nanosensors which are highly sensitive to food-producing gases as they spoil. The mechanism of nanosensors is that the sensor strip changes its colour when there is detection in contamination of food articles and any gaseous detection (Nelson et al., 2013). The use of nanosensors in food packaging can also aid in determining the nutrient content and consistency of the product. Researchers have used nanosensors to classify pathogen and mycotoxin in foods. It is difficult to conventionally detect such microorganisms, but the nanosensor can quickly detect toxins and pathogens in food, processing and storage areas (McClements, 2015). Such nanosensors are made of small materials based on silicone that can identify proteins and detect pathogenic bacteria and viruses (Challa, 2007). Table 3 illustrate the general uses of nanotechnology in food packaging.

\section{FOOD SAFETY}

Nanotechnology innovations move the food industry at full pace. The use of 'active' or 'smart' packaging aimed at improving food safety and quality as well as extending the shelf life of items. Nanosensors installed in the food packaging materials can help track any physical, chemical or even biological changes during the food processing phase.

The smart packaging was designed to detect toxins, food pathogens and chemicals through a special nanosensor (consisting of a series of nanosensors) and nano device. Nanotechnology recently allowed nanosensors to be developed for the detection of foodborne 
pathogens or toxins (Doyle et al., 2006): Staphylococcus sp. immunosensing Enterotoxin B with poly (dimethylsiloxane) (PDMS) strengthened, protected, fluid bilayer membranes( $r$ SBMs) and unique antibodies for particular toxins (Dong et al., 2006).

Table 3: Use of nanotechnology in food packaging

\begin{tabular}{llc}
\hline Sr. No. & Uses/Concept & References \\
\hline 1. & $\begin{array}{l}\text { The two nanomaterials i.e. nano-clays and nanosilver are mostly used } \\
\text { in advance packaging. These materials can enhance the packaging } \\
\text { quality and also work as barrier for microorganisms. }\end{array}$ & Drew and Hagen, 2016 \\
&
\end{tabular}

2. Nanoparticles of silica in combination of plastic polymer can prevent

Seval K, 2015 oxygen penetration with increasing shelf life of product.

3. Nanocoating on different fruits and vegetables leads to the protection

Shivendu et al., 2014 form undesirable humidity and oxygen concentration e.g. tomatoes

4. Nanocomposite films with antimicrobial activity can greatly reduce the

Radha et al., 2014 growth of pathogenic and spoilage microorganism.

5. Gold nanostructures, carbon nanotubes and quantum dots have been used as sensors in packaging to ensure food safety.

6. Ag nanoparticle have ability to restrict bacterial growth. It decreases microbial growth and enhance sensorial characteristics of food.

Seyed et al., 2014

Motlagh et al., 2012

7. Nanoinforcement are used to provide extra tensile strength to the
packaging material by using combination of nanoclay, cellulose etc.

7. Nanoinforcement are used to provide extra tensile strength to the
packaging material by using combination of nanoclay, cellulose etc.

Arora and Padua, 2010

8. Nanocomposite active packaging deals with antimicrobial, oxygen Huang et al., 2010 barrier and enzyme immobilization system.

9. Nanocomposite smart packaging contain nanosensors/biosensors which obtain data like temperature, gas, $\mathrm{pH}$ etc.

Robinson and Morrison, 2010

10. Opal film integrating carbon black nanoparticle $(50 \mathrm{~nm})$ was used as Afroz et al., 2010 biosensor that reacts when food get spoiled.

At the other hand, recent reports of detecting bacterial toxins using nanoparticles technology have been reported (Zhu et al. 2014). To detect most dangerous food pathogens such as Listeria monocytogenes, E. Coli and Salmonella sp. a variety of biosensors were developed. It is also reported that the use of magnetic nanoglodimmuno sensor could detect aflatoxins generated by Aspergillus flavus which contaminate food products (Tang et al., 2009). Nanobarcodes was used to determine the presence of food pathogen by measuring the reactivity of fluorescent probe under UV light. For detection of Listeria monocytogenes in milk sample, immobilized oligonucleotide probe with magnetic nanoparticles have been used. Electronic tongue nanosensors (detection rate part per trillion) could be used as color altering system when food get spoiled. Nanofunctionalized gold electrode (based on catalysis of lipid peroxidation on cell membrane) is used for quantification of bacteria in milk samples (Shivendu et al., 2014). Many companies and universities have developed intelligent packaging to warn when contamination of the packaged food reacts to environmental changes, tears and selfrepairing hole conditions. (Ravichandran, 2010). 


\section{FUTURE OF NANOTECHNOLOGY}

Nanotechnology is predicted to nearly triple in value in the food industry to $\$ 30.5$ billion by 2025 , with many emerging research fields. Engineered nanotech compounds may add great benefits to antimicrobial surfaces, sensors that change color as food begins to deteriorate especially in terms of enhanced solubility and bioavailability, as well as in food packages. More than 1,000 businesses are now working on products focused on nanotechnology with an emphasis on R\&D. Enzymes can be immobilized for future applications in order to improve their efficiency and reuse, and to produce new food texture using nanoscale structures. Researchers are focusing on how nanotechnology can be used in the food sector and the benefits of nanotechnology research are expected to include improved production and delivery of pesticides and biocides, safer animal feed and feeding quality improvements, nano barcodes for better traceability at all stages of processing and transportation, and reformulation of foods that are lower in fat, salt and sugar while maintaining food taste and aptitude. Several nanosystem are still in the development phase, and finding nanocomponent efficacy in food application will take some time. Researchers are attempting to develop more efficient nanocarriers that can deal with increasing bioavailability without affecting the original food product taste and appearance. The new type of sensor is being designed to make food packaging safer i.e. antigen-based biosensors that detect the presence of specific microorganisms responsible for spoiling food products. In the future, nanotechnology would use some forms of transistors based on RFID technologies which would be able to track minor variations in food properties such as pressure, temperature and $\mathrm{pH}$. Other than this, nanoencapsulation will take on major credit for nanotechnology by encapsulating essential nutrients and providing them with an efficient nano delivery system within the body (Neha et al., 2015; Cerqueira at al., 2019).

In the food and feed industries too, the future of nanotechnology is questionable. Although the use of nanotechnology provides many potential and practical benefits, customer knowledge about the technology is lacking. Although it is very difficult to forecast how customers will react to current and future applications of nanotechnology, there is no question that market consumer acceptance will be critical if it is to be widely used in future.

\section{CONCLUSION}

The goal of nanotechnology in the food sector is to make efficient use of the technique in the different food sector-related fields such as food processing, food packaging, food preservation, and food safety. With the advancement of different technologies in food industry, nanotechnology is implementing its uniqueness in the food sector. The scientists are now focusing on nanoencapsulation in food processing and food packaging. This technology promises improved food processing and packaging techniques with keeping the safety of food products and also addresses flavour, nutrition and quality enhancement in food products. This technique also retains its interest in 'functional foods' where food carries medicinal ingredients and supplements and can help to improve productivity. The nanoencapsulation technique plays a very effective role in combating bioactive compound absorption in our body. Nano-biosensor provides a fast and accurate analytical method compared with conventional food analytical methods. The use of both the mix of DNA and nanotechnology work would open up a new field of nutrient delivery method in the future. Among other nanotechnology benefits to the food 
industry, nanomaterial safety issues cannot be neglected. The safety problems with nanoparticles are not well known but their propensity for hazard is obvious because of the highvolume ratio to the surface layer, which would make the particles very reactive or catalytic. Therefore, these can move across the cell membranes of organisms and can interfere with biological organs. Therefore, scientists or researchers concerned with the development of nanotechnology in different sectors should give priority to food safety and other regulations should be introduced to make it compulsory testing of the food product before it is placed in the market.

\section{REFERENCES}

Afroz, QM, Swaminathan K, Karthikeyan P, Ahmed KP, Sudhir U, Kumar MU.(2010) Application of nanotechnology in food and dairy processing: an overview. Pak J Food ScI: 22: 23-31

Agrawal S. and Rathore P (2014). Nanotechnology pros and cons to agriculture: a review. Int J Curr Microbiol App Sci, 3(3), 43-55.

Anu K, Bhanu M and Harsha K 2015). Advancement of Nanotechnology in Food Packaging. World Journal of Pharmacy and Pharmaceutical Sciences Volume 4, Issue 04, 1054-1057.

Arafat SM and Basuny AM. (2019). Nanotechnology in food systems: Application and safety. World Journal of Advanced Research and Reviews, 2(2), 19-24.

Arora A and Padua GW. (2005) Review: nanocomposites in food packaging. J Food Sci. 75(1): 43-49. doi: $10.1111 /$ j.1750-3841.2009.01456.x.

Arora A, Padua GW (2010) Review: nanocomposites in food packaging. J Food Sci 75:R43-R49

Augustin, M.A., Hemar, Y. (2009). Nano and micro-structured assemblies for encapsulation of food ingredients. Chem. Soc. Rev. 38, 902-912

Baker, S.N.; Baker, G.A. (2010). Luminescent carbon nanodots: Emergent nanolights. Angew. Chem. Int. Ed. Engl., 49, 6726-6744.

Bhattachary S, et al. Biomems and nanotechnology based approaches for rapid detection of biological entities. J. Rapid Methods Auto Microb. 2007; 15:1-32.

Bradley, E. L., Castle, L., and Chaudhry, Q. (2011). Applications of nanomaterials in food packaging with a consideration of opportunities for developing countries. Trends Food Sci. Technol. 22, 603-610. doi: 10.1016/j.tifs.2011.01.002

Cerqueira A and Pastrana M (2019). Does the Future of Food Pass by Using Nanotechnologies? Frontiers in Sustainable Food Systems. Vol 3, Page 16 https://doi.org/10.3389/fsufs.2019.00016

Challa K, (2007). Nanomaterials for Biosensors, Wiley-VCH, Weinheim, Germany https://www.bookdepository.com/Nanomaterials-for-Biosensors-Challa-S-S-RKumar/9783527313884.

Chaudhry Q, Scotter M, Blackburn J, Ross B, Boxall A, Castle L et al (2008) Applications and implications of nanotechnologies for the food sector. Food Addit Contam A 25:241-258

Clara S, Donatella D and Sossio C. (2011) Food packaging based on polymer nanomaterials. Progress in Polymer Science.;36(12):1766-1782.

Cushen, M., Kerry, J., Morris, M., Cruz- Romero, M., Cummins, E. (2012). Nanotechnologies in the food industry - recent developments, risks and regulation. Trends Food Sci. Technol., 24: 3046.

Degant O, Schwechten D (2002). Wheat flour with increased water binding capacity and process and equipment for its manufacture. German Patent DE10107885A1, 2002

Dong, Y., Phillips, K.S., Cheng, Q. (2006). Immunosensing of Staphylococcus exterotoxin B (SEB) in milk with PDMS microfluidic systems using reinforced supported bilayer membranes (r-SBMs). Lab on a Chip,6: 675681.

Doyle, E. (2006). Nanotechnology: A brief literature review. Food Research Institute, University of Wisconsin Madison. 
Drew, R., \& Hagen, T. (2016). Nanotechnologies in food packaging: An exploratory appraisal of safety and regulation.

Drexler, E.K. (1986) Engines of Creation: The Coming Era of Nanotechnology; Anchor Press: Garden City, NY, USA.

Ezhilarasi, P. N., Karthik, P., Chhanwal, N., and Anandharamakrishnan C. (2013). Nanoencapsulation techniques for food bioactive components: a review. Food Bioprocess Technol. 6, 628-647. doi: 10.1007/s11947-012-0944-0

Gupta, A., Silver, S. (1998). Molecular Genetics: Silver as a biocide: Will resistance become a problem? Nature Biotechnol., 16: 888.

He, X., Hwang, H. (2016). Nanotechnology in Food Science: Functionality, Applicability and Safety Assessment, Journal of Food and Drug Analysis, 24:671-681.

Huang Q, Yu H, Ru Q (2010) Bioavailability and delivery of nutraceuticals using nanotechnology. J Food Sci 75(1):R50-R57

Hyunjong Y, Jun-Young P, Chang Woo K, Sung-Chul H, Kyung-Min P, and Pahn-Shick C (2018). An Overview of Nanotechnology in Food Science: Preparative Methods, Practical Applications, and Safety. Hindawi Journal of Chemistry Volume 2018, Article ID 5427978, 10 pages https://doi.org/10.1155/2018/5427978.

Iijima, S. (1991) Helical microtubules of graphitic carbon. Nature, 354, 56-58.

Kah, M., Hofmann, T. (2014). Nanopesticide research: current trends and future priorities. Environ. Int., 63: 224235.

Kavitha P, Manjunath M and Huey-Min H (2017). Nanostructures: Current uses and future applications in food science. journal of food and drug analysis $25\left(\begin{array}{llll}2 & 0 & 1 & 7\end{array}\right) 245$ e2 53 http://dx.doi.org/10.1016/j.jfda.2017.02.004

Khan RA, Khan NM, Nisar A (2015) Nanotechnology and Food. Is Nanotechnology for Food Applications Safe? : A Review. Nanosci Technol 2(3): 1-7.

Kookana, R.S., Boxall, A.B.A., Reeves, P.T., Ashauer, R., Beulke, S.,Chaudhry, Q. (2014). Nanopesticides: guiding principles for regulatory evaluation of environmental risks. J.Agricult. Food Chem., 62: 42274240.

Krishnakumar T., (2019) Nanotechnology in Food Processing and Packaging. Nanoparticles in Food Packaging, DOI: 10.13140/RG.2.2.30391.16805

Mazzocchi S. 5 Things you need to know about nanofoods. 2011. Available from: http://www.pbs.org/wnet/need-toknow/five-things/nanofoods/6682/

McClements DJ. Nanoscale Nutrient Delivery Systems for Food Applications: Improving Bioactive Dispersibility, Stability, and Bioavailability. J Food Sci. 2015;80(7):N1602N1611. doi:10.1111/1750-3841.12919

Mihindukulasuriya, S. D. F., and Lim, L. T. (2014). Nanotechnology development in food packaging: a review. Trends Food Sci. Technol. 40, 149-167. doi: 10.1016/j.tifs.2014.09.009

Momin, J.K., Jayakumar, C., Prajapati, J.B. (2013). Potential of nanotechnology in functional foods. Emirates J. Food Agricult., 25(1): 1019.

Motlagh NV, Mosavian MTH, Mortazavi SA, Tamizi A (2012) Beneficial effects of polyethylene packages containing micrometer-sized silver particles on the quality and shelf life of dried barberry (Berberis vulgaris). J Food Sci 77:E2-E9

Moustafa M. (2016). An Overview of Nanotechnology in Food Industry. DOI: 10.13140/RG.2.2.27391.61601

Mozafari, M.R., Flanagan, J., Matia-Merino, L. (2006). Recent trends in the lipidbased nanoencapsulation of antioxidants and their role in foods. J. Sci. Food Agricult., 86: 2038 2045.

Mozafari, M.R., Johnson, C., Hatziantoniou, S., Demetzos, C. (2008). Nanoliposomes and their applications in food nanotechnology. J. Liposome Res.,18(4): 309327.

Nanotechnology in Food. Nano Werk. Accessed 23 June 2020. https://www.nanowerk.com/nanotechnology-in-food.php 
National Nanotechnology Imitative (2020). Benefits and application. Nano.gov Accessed on June 21, 2020. https://www.nano.gov/you/nanotechnologybenefits : : : text=Energy\%20Applications\&text=Nanotechnology\%20is\%20improving\% 20the\%20efficiency, efficiency\%20combustion\%20and\%20decreased\%20friction.

Neha P, Surjit S, Nupur O, Anamika S, Anil B, Vivek R, and Sutapa B (2015). Facets of Nanotechnology as Seen in Food Processing, Packaging, and Preservation Industry. BioMed Research International. Nov 03, 2015 https://doi.org/10.1155/2015/365672

Nelson D and Priscyla M (2013). "Nanobiotechnology perspectives. Role of nanotechnology in the food industry: a review," International Journal of Food Science Technology, vol. 48 , no. 6, pp. 1127-1134.

Pakeeza R, Zeeshan J, Faisa A, Ayesha A and Shahid R (2019). Potent Implications of Nanotechnology in Food Industries. LGU Journal of Life science 3(2):LGUJS MS.ID- 071 (2019)

Pasa, Andre A (2010). "Chapter 13: Metal Nanolayer-Base Transistor". Handbook of Nanophysics: Nanoelectronics and Nanophotonics. CRC Press. Pp. 13-1, 13-4. ISBN 9781420075519.

Peshev D, Peeva LG, Peev G, Baptista IIR, Boam AT (2011) Application of organic solvent nanofiltration for concentration of antioxidant extracts of rosemary (Rosmarinus officiallis L.). Chem Eng Res Des 89:318-327

Pinto, R. J. B., Daina, S., Sadocco, P., Neto, C. P., and Trindade, T. (2013). Antibacterial activity of nanocomposites of copper and cellulose. BioMed Res.Int. 6:280512. doi: $10.1155 / 2013 / 280512$

Radha K, Amitha T and Sathian C (2014). Application of nano technology in dairy industry: prospects and challenges - A Review. Indian J. Dairy Sci. 67(5), 2014

Ravichandran R. (2010). Nanotechnology Applications in Food and Food Processing: Innovative Green Approaches, Opportunities and Uncertainties for Global Market, International Journal of Green Nanotechnology: Physics and Chemistry, 1:2, P72-P96, DOI: $10.1080 / 19430871003684440$

Renton, A. (2006). Welcome to the World of Nano Foods. Available at: http://observer.guardian.co.uk/foodmonthly/futureoffood/story/0,1971266,00.html [accessed January 17, 2008]

Rhim, J.-W., Hong, S.-I., Park, H.-W., Ng, P.K.W. (2006). Preparation and characterization of chitosan-based nanocomposite films with antimicrobial activity. J. Agricult.Food Chem., 54: 58145822.

Robinson DKR, Morrison MJ (2010) Nanotechnologies for food packaging: reporting the science and technology research trends: report for the ObservatoryNANO. http://www.observatorynano.eu/project/filesystem/files/Food\%20Packaging\%20Report $\% 202010 \% 20$ DKR\%20Robinson.pdf.

Roselli, M., Finamore, A., Garaguso, I., Britti, M. S., and Mengheri, E. (2003). Zinc oxide protects cultured enterocytes from the damage induced by Escherichia coli. J. Nutri. 133, 4077-4082.

Rothemund, P.W.K. (2006). Folding DNA to create nanoscale shapes and patterns. Nature, 440, 297-302.

Sekhon, B.S. (2010). Food nanotechnology an overview. Nanotechnol. Sci. Appl.,3: 115.

Seval K (2015). CURRENT AND FUTURE APPLICATIONS OF NANOTECHNOLOGY IN THE FOOD INDUSTRY. S.S. KIRDAR/ ISITES2015 Valencia -Spain

Seyed A, Marzieh G and Mohsen K (2014). Safety of Nanotechnology in Food Industries. Electronic physician; Volume 6, Issue 4, October-December 2014. http://www.ephysician.ir

Sherman LM. Chasing nanocomposites. 2005. Available from: http://www.ptonline.com/articles/200411fa2.html 
Shivendu R, Nandita D, Arkadyuti C, S. Melvin S, Chidambaram R, Rishi S and Ashutosh K (2014). Nanoscience and nanotechnologies in food industries: opportunities and research trends. J Nanopart Res (2014) 16:2464 DOI 10.1007/s11051-014-2464-5

Singh T, Shukla S, Kumar P, Wahla V, Bajpai K. and Rather A (2017). Application of Nanotechnology in Food Science: Perception and Overview. Frontiers in Microbiology. Vol 8, Page 1508 DOI=10.3389/fmicb.2017.01501

Suthar TR, Sanghvi RV, Nair TK, Devkatte AN and Chaudhari DN (2019). Review and Future Prospects for Lab-Grown Meat. Research Review International Journal of Multidisciplinary Volume 4 Issue 4 Page 1885-1892.

Sze, Simon M. (2002). Semiconductor Devices: Physics and Technology (PDF) (2 ${ }^{\text {nd }}$ ed.). Wiley. p. 4. ISBN 0-471-33372-7.

Tanet, H., Ma, R., Lin, C., Liu, Z., and Tang, T. (2013). Quaternized chitosan as an antimicrobial agent: antimicrobial activity, mechanism of action and biomedical applications in orthopedics. Int. J. Mol. Sci. 14, 1854-1869. doi: 10.3390/ijms14011854.

Tang, D., Sauceda, J. C., Lin, Z., Ott, S.,Basova, E., Goryacheva, I., Biselli, S., Lin, J., Niessner, R., Knopp, D. (2009). Magnetic nanogold microspheresbased lateral-flow immunodipstick for rapid detection of aflatoxin B2 in food. Biosens. Bioelectron., 25: 514518.

Vargas, M., Pastor, C., Chiralt, A., McClements, D.J., Gonzalez-Martinez, C. (2008). Recent advances in edible coatings for fresh and minimally processed fruits. Crit. Rev. Food Sci. Nutr., 48: 496511.

Vidhyalakshmi, R., Bhakyaraj, R., Subhasree, R.S. (2009). Encapsulation The future of probiotics A review. Adv. Biol. Res., 3 4: 6103.

Weiss, J., Takhistov, P., and McClements, J. (2006). Functional materials in food nanotechnology. J. Food Sci. 71, R107-R116. doi: 10.1111/j.1750-3841.2006.00195.x

Xiaojia H, Hua D, Huey-min H (2018). The current application of nanotechnology in food and agriculture. Journal of food and drug analysis. https://doi.org/10.1016/j.jfda.2018.12.002

Xu, X.; Ray, R.; Gu, Y.; Ploehn, H.J.; Gearheart, L.; Raker, K.; Scrivens, W. A. (2004). Electrophoretic Analysis and Purification of Fluorescent Single-Walled Carbon Nanotube Fragments. J. Am. Chem. Soc., 126, 12736-12737.

Yu, H., Huang, Y., Huang, Q. (2009). Synthesis and characterization of novel antimicrobial emulsifiers from -polylysine. J. Agricult. Food Chem.,58: 12901295.

Yu, H.L., Huang, Q.R. (2010). Enhanced in vitro anti-cancer activity of curcumin encapsulated in hydrophobically modified starch. Food Chem., 119:669 674.

Zhu, K., Dietrich, R., Didier, A., Doyscher, D., Märtlbauer, E. (2014). Recent developments in antibody-based assays for the detection of bacterial toxins. Toxins, 6: 13251348.

Received: 28 ${ }^{\text {th }}$ Jule 2020; Accepted: 20 ${ }^{\text {th }}$ August 2020; Published: 14th September 2020. 